\section{How am I prepared to address these issues?}

If I am elected to the position of vice-president, president-elect, I will depend heavily on ideas from members for ways in which we can meet the challenges of the 1990s. I am committed to the concept of a member-driven organization. At any time, I welcome comments and suggestions from members (active or inactive) about how ACRL can address these issues.
Because I have participated in every type of unit operating in ACRL, I understand fully how ACRL works. I also understand the importance of leadership to the organization. I am prepared to provide that leadership in addressing these issues and representing ACRL.

Patricia A. Wand is assistant university librarian for public services at the University of Oregon, Eugene.

\title{
Libraries and telecommunications
}

\section{technologies}

\author{
By Linda Bigelow \\ Project Consultant \\ Northern Illinois Learning Resources \\ Cooperative
}

\author{
and Alice Calabrese \\ Project Director \\ Northern Illinois Learning Resources \\ Cooperative
}

\section{A survey of the literature, with an emphasis on networks.}

$\mathbf{W}$ hat are the new telecommunications technologies and how well have they been adapted to the needs of libraries? These two questions were the focus of a recent survey of the literature as part of an LSCA Title III grant project funded by the Illinois State Library. The purpose of the grant was to research the requirements for a statewide library telecommunications network in Illinois.

\section{Telecommunications technology}

The convergence of telecommunications and technology was frequently cited in the literature as the driving force behind today's telecommunications trends. Goldstein (1988) saw this convergence as both "confusion and opportunity" (p.36). Noam (1987) described in detail the resulting shift in the concept of public telecommunications from a centralized, hierarchical, universally accessible network (characterized by AT\&T before divestiture) to "a new one that is open and loosely intercon- nected, resembling a federation of subnetworks much like the system prevailing in transportation" (p.30). The shift toward an information-based service economy has created great user demands for high-speed, low-cost telecommunications at the same time that decentralized services have reduced the former economies of scale that increased technological options are available.

West (1984) commented on the trend toward distributing powerful information processing capacity to individuals and connected this decentralization to "increasing demand to link this dispersed...power via a digitized, integrated (voice, video, and data) telecommunications network so that individuals can communicate with each other" (p.2).

The integration of voice, video, and data was one of the primary trends found in the literature. Integration was discussed on several levels. In 1984, West was calling for colleges and universities to work toward integration of communication 
technologies on campuses and for coordination and consolidation of management of those technologies to create a "network of networks." Apparently, the academic community agreed with West.

Temple University (Scanlon and Patterson 1984), the University of Michigan ("University" 1985), Virginia Tech (Blythe 1986; Lilly 1985), Cornell (Paul 1985), Brandeis (“At Brandeis" 1985), Dallas County Community College District (J.R. Hill 1987/88), and Maricopa County Community College District (Doucette 1987) all reported merging their communications systems into integrated networks under centralized management.

Integration of voice, video, and data on a global basis in the form of an Integrated Systems Digital Network (ISDN) has been in the development stage for the past fifteen years. The Consultative Committee for International Telegraph and Telephone (CCITT), sponsored by the United Nations, is overseeing the setting of standards for ISDN. Blankenhorn (1986), Harper (1987), Miller (1987), and Underwood (1987) described the development of ISDN and the problems faced in implementing such a global network.

The main problems facing ISDN are lack of agreement on international standards for the technology needed and the high cost of putting the network in place. The world's largest telephone companies are taking the lead in trying to implement ISDN. In the United States, AT\&T and the Bell Operating Companies (BOCs) are beginning to replace their central office switches with digital switches, a necessary step in the implementation process. This will be a long and costly process because about 12,000 switches need to be replaced at a cost of $\$ 6$ million each.

Miller predicted that ISDN will be in place by the mid-1990s. He also predicted that a "proliferation of so called near-ISDNs is...likely to accelerate during the next few years" as systems are designed to take advantage of current technology (p.37). These systems will be upgradeable to CCITT standards when those standards become available.

ISDN has its critics. Many experts do not expect to see a true single ISDN develop. Rather, they "envision multiple ISDNs intersecting in a variety of ways but with enough uniformity to make services possible that are now impossible" (Miller, p.38).

Whether or not ISDN becomes a reality, several trends are still evident. Rudd (1987) states that telecommunications networks will be operating at higher data rates and will provide increased connectivity and communication capabilities. The networks will provide widespread access to public data networks. There will be user demand for increased bandwidth. The costs of electronics and basic transmission will decrease, but the new complexity of the networks will require more skilled personnel to manage and support the networks. Noam (1987) points out that transmission facilities will continue to change from analog to digital technology.
One digital transmission facility expected to play a key role for the next several years is fiber optics (Rocher 1987). Fiber optics consists of thin strands of fiber made of transparent material such as glass or plastic through which light pulses are transmitted. Each strand is capable of carrying the equivalent of 6,000 voice messages at one time.

The signals are not susceptible to electrical noise, lightning, or other forms of electromagnetic interference, and are impervious to temperature or moisture. Fiber optics technology provides high bandwidth, low signal loss, and security advantages (Ohlhaber 1987). Telephone companies are moving to install fiber optic networks in the United States (McCourt and Robinson 1986). As Welter (1987) states, fiber is becoming "the medium of the future for most point-to-point long-distance voice and data communications" (p.50).

According to Trafton (1987), another trend in technology is that "data, text and video are filling an even greater share of the communication applications" (p.38). Satellite technology is playing a significant role in serving those applications. Gershon (1987) anticipates that satellites "will become the primary vehicle for video communications, point-to-multipoint communications and thin-route applications" (p.25). Welter adds that "the appeal of bypassing the public switch network, ease of installation, and distanceindependence often make satellites the economical choice fur communication in remote areas" (p.50).

Satellites are particularly good for reaching remote or scattered locations where it is not economical to build fiber networks. Satellites have proven to be useful in library and education settings for providing video teleconferencing and for delivery of distance learning (Brumm 1984; Portway 1987; “Teleconferencing” 1987/88; Wolf 1987).

According to Welter, the introduction of VSATs (Very Small Aperture Terminals) has considerably reduced data communications costs via satellite when compared to costs for leased telephone lines for networks with widely dispersed locations.

The advantages and disadvantages of fiber optics and satellite networks were thoroughly discussed in the literature. However, there was a general agreement that there is a place for both. In fact, a hybrid network designed to take advantage of the strengths of not only fiber optics and satellites but microwave and cable and other existing transmission methods as well as proposed (Castiel 1985; Pelton and McDonegal 1987; Stephens 1986; Welter 1987). According to Pelton, "There is a growing realization...that the issue is not satellite vs. terrestrial transmission media, but rather how best to corilbine satellites and terrestrial transmission media in a dynamic and optimally-designed ISDN network" (p.62).

\section{Library services}

The literature reflects the growing awareness and interest of librarians for integrating telecom- 
munications into their services. However, Berry (1986) expressed concern that librarians have neither been able to keep up with the rapidly changing field of information technology nor developed sufficient tools for evaluating the technologies to make crucial decisions. He urged the establishment of an agency to evaluate new technology, disseminate the information, and report on new developments and current applications of the technology in libraries.

L.L. Hill (1985) outlined some of the barriers and benefits of corporate library participation in library networks. Boss (1985) discussed the need for adopting standards for interconnecting health sciences libraries, recommending the Open System Interconnection (OSI) reference model as the most appropriate mechanism. Boss referred to the Linked Systems Project (LSP) as an example of a library network based on the OSI model. The Linked Systems Project allows the Library of Congress, the Research Library Group, the Western Library Network, and OCLC to share and exchange data among their various kinds of computer systems. "While the computer-to-computer link will first be used for the exchange of authority data, it will also encourage the later sharing of full catalog records, location and holdings data, the transmission of interlibrary loan requests, communication with vendors, and other services" (p.336).

Several successful library networks were described in the literature. Among them were ALANET (Lee 1986), an electronic information service providing electronic mail and current awareness services as well as gateways to various databases, and the Vermont Automated Libraries System (VALS) ("Vermont" 1985), a statewide information system linking separate but compatible computer systems. VALS provides geographically distributed access to library and information databases from any library, office, or home within the state with access to an appropriately equipped computer terminal.

The Colorado Alliance of Research Libraries (CARL) System (Culkin and Shaw 1985) is a computer network among Colorado libraries. Octanet (Gadzikowski 1987) is a computer-based telecommunications network for the delivery of interlibrary loan services, electronic messaging, online union lists, and management reports to the Midcontinental region of the National Library of Medicine's Regional Medical Library network.

The North Carolina Information Network (McGinn 1987) is an effort on the part of the North Carolina State Library to provide the most up-todate information possible to all geographic areas of the state. Services provided by the network include a statewide online union catalog and union list of serials, electronic mail/bulletin board system, and telefacsimile for transmission of documents. The Network also provides an in-state toll-free 800 number connecting to the computer service, Tym- net, and Telenet to reduce dial access telecommunications charges.

The Oregon Public Access Catalog (Vennison 1988) provides access to databases of interest to residents of the state. Several databases have been developed including a statewide newspaper index, a directory of government services, and outside vendor files. Users of the network include the state government, local libraries, the general public, and education.

At a 1985 conference on networking held in California (Nyren 1985), recommendations for the development of a framework for multitype cooperation in a network were developed. The recommendations included providing for:

- equity in governance;

- voluntary membership;

- local control;

- new sources of funding;

-statewide coordination and communication;

- accommodation with other existing networks and cooperatives;

-equitable access for all users in all geographic areas;

- funding for experimentation;

-incentives for networking;

- incorporation of established statewide systems;

- definition of responsibilities for services, determination of fees, procedures, and protocols;

- definition of criteria for network membership.

Doucette (1987) pointed out the need to plan for expandability of a network to avoid obsolescence and the need for broadbased involvement of the users of the network in the planning process.

One telecommunications technology that is gaining widespread acceptance in the library community is telefacsimile transmission (fax). In a special report in American Libraries, several fax projects were described. Washington state (Moore 1988) completed a large-scale, two-year demonstration Materials Delivery Project combining a network of libraries equipped with fax with a statewide ground courier system.

Illinois' facsimile network (Mak 1988), which links over 150 fax sites, was described from the perspective of a large reference and research center. The College of Physicians of Philadelphia (Aguirre 1988) developed a fax network for the fast delivery of medical information. A large city/county library in Ohio (Davis 1988) used fax to communicate with its branch libraries. Montana (Brander 1988) created the Montana Faxnet Project to demonstrate the use of fax for document retrieval for five sectors: governmental, business, legal, medical, and educational.

Lynch (1986) summarized the importance of libraries becoming involved in the "telecommunications landscape":

"If libraries are to survive as viable services, they must not only understand current computing and telecommunications technologies, but they must 
develop and execute plans to implement these technologies. This is an issue at all levels: local, state, regional, and national. Doing so will require money, talent, education, creativity, determination, consensus, management, and most of all, vision" (p.46).

\section{Conclusions}

The convergence of telecommunications and technology will result in greater decentralization of information processing capacity. The possibility now exists of integrating voice, video, and data transmission networks. Telecommunications networks will provide higher speeds and increased bandwidth capacity through the conversion of analog to digital transmission.

Fiber optics and satellite technologies will be key components in telecommunications networks.

More telecommunications services will be available to libraries and more libraries will take advantage of those services. Telecommunications will promote greater resource sharing and more networking among libraries. Librarians and patrons will increase their computer and telecommunications literacy.

Transmission of full-text documents will become the norm as data speeds increase and telecommunications costs decrease. New storage and delivery capabilities will be available to increase library services.

While these trends in technology offer exciting possibilities for libraries, it must be remembered that technology itself is but the means to an end. Kooser (1987) said it well:

"The key concept to keep in mind when planning for new technology is that the development of an information system is a strategic decision, not a technological one. It should rely on the organization's goals and basic methods of operation, rather than on what's new in the marketplace" (p.66).

\section{References}

Aguirre, Anthony, "Libraries Fast-Fax for Physicians," American Libraries 18 (January 1988): $61-62$.

"At Brandeis, Comprehensive Communications," American School and University 58 (December 1985): 29 .

Berry, John, "High Hopes \& Headaches" [Editorial], Library Journal 111 (October 1, 1986): 4.

Blankenhorn, D., "Waiting for ISDN," Datamation 32 (July 1, 1986): 83-88.

Blythe, E., "The Cutting Edge of Network Technology," Cause/Effect 9 (January 1986): 8-11.

Bormann, E.G., and N.C. Bormann, Effective Small Group Communication. Minneapolis: Burgess, 1972.

Boss, Richard W., "The Open System Interconnection as a Building Block in a Health Sciences Information Network," Bulletin of the Medical Li- brary Association 73 (October 1985): 330-36.

Brander, Linda, "Fax Goes far in Montana," American Libraries 18 (January 1988): 63-64.

Brumm, L., "A Dish on Every Rooftop?" VocEd 59 (April 1984): 22-24.

Castiel, D., "Hybrid Networks Hold Great Promise if Designed with the Proper Tools," Data Communications 14 (July 1985): 121-26.

Culkin, P., and W. Shaw, "The CARL System" [Colorado Alliance of Research Libraries], Library Journal 110 (February 1, 1985): 68-70.

Davis, Eve J., "A City/County Library Tries Intra-Faxing," American Libraries 18 (January 1988): 62-63.

Desramaux, R.J., "COMNET: A Broadband Voice, Video and Data Network for the Canadian House of Commons-(3) The Impact." In J.M. Bennett and T. Pearcey (eds.), The New World of the Information Society: Proceedings of the 7th International Conference on Computer Communications, Sydney, October-November 1984. Amsterdam: North-Holland, 1985. pp. 375-79.

Doucette, D. "Computer Networks in Community Colleges," Community, Technical, and Junior College Journal 58 (October/November 1987): 40-44.

Expansion and Enhancement of the Library Computer System in Illinois: A Proposal for Support through the Higher Education Cooperation Act. Springfield: Illinois Board of Higher Education, November 1987.

Final Report of the Blue Ribbon Task Force on the Illinois Library Systems Study. Springfield: Illinois State Library, December 1987.

Gadzikowski, C., "Octanet-An Electronic Library Network, the First Four Years: Summary and Evaluation," Information Technoloy and Libraries 6 (June 1987): 138-43.

Gershon, R.A., "Satellite and Fiber Optics: Redesigning the Business of Long-haul Transmission," Business Communications Review 18 (March/April 1987): 12-25.

Goldstein, M.L., "Telecommunications: Solutions in Search of Problems," Industry Week 224 (January 1988): 36-40.

Harmon, K.R., Telecommunications Study for Colorado Libraries: Executive Summary. Denver: Colorado State Library, February 1986.

Harper, M., "New Directions in Telecommunications," Nation's Business 75 (April 1987): 38-40.

Hill, J.R., "Voice, Data and Video In-house in Dallas," Teletrends 4 (Winter 1987/88): $4+$.

Hill, L.L., "Issues in Network Participation for Corporate Librarians," Special Libraries 76 (Winter 1985): 2-10.

Kooser, W.W., "Taming Technology," Today's Office, June 1987, pp. 65-66.

Lee, Joel M., "ALANET: A Multifaceted Information Service," Online 10 (May 1986): 114-20.

Lilly, J.L., "Organization for Communications Network Series," Cause/Effect 8 (July 1985): 28-32. 
Lynch, C.A., and E.B. Brownrigg, "The Telecommunications Landscape: 1986," Library Journal 111 (October 1, 1986): 40-46.

McCourt, J.W., and R.L. Robinson, "Midwest Fiber-Optic Cable Project," Telecommunications 20 (October 1986): 116-17.

McGinn, H., "Information Networking and Economic Development," Wilson Library Bulletin 62 (November 1987): 28-32.

Mak, Collette, “"Fax is Integral - - To Center's Vast Operation," American Libraries 18 (January 1988): 60-61.

Mazutis, J., and J. Philiips, "COMNET: A Broadband Voice, Video and Data Network for the Canadian House of Commons-(1) The Requirements." In J.M. Bennett and T. Pearcey (eds.), The New World of the Information Society: Proceedings of the 7th International Conference on Computer Communications, Sydney, OctoberNovember 1984. Amsterdam: North-Holland, 1985. pp. 364-68.

Miller, R., "Integrated Services Digital Network (ISDN): Telecommunications in the Future," Online 11 (March 1987): 27-38.

Moore, M.Y., "Fax it to Me: A Library Love Affair," American Libraries 18 (January 1988): 57-59.

Noam, E.M., “The Public Telecommunications Network: A Concept in Transition," Journal of Communication 37 (1987): 30-48.

Nyren, Karl, "California Conference on Networking: First Steps Taken to Mobilize State’s Library Communities to Build Statewide Muititype Network," Library Journal 110 (November 15, 1985): 12-14.

Ohlhaber, R., "Fiber Optics: A Technical Tutorial," Sound and Communications, May 1987, pp. 22-24.

Paul, P., "2lst Century Telecommunications: Cornell's New Voice-Data Link Will Serve the 1990's-and Beyond," American School and University 58 (September 1985): 55-60.

Pelton, J.N., and P.J. McDonegal, "Don't Overlook Satellites," Telephone Engineer and Manage- ment 9 (March 1, 1987): 61-62.

Plan for Funding Automated Resource Sharing in Illinois Libraries: Revised Draft. Springfield: Illinois State Library, May 1988.

Portway, P., "Meetings Take on a New Look," Modern Office Technology Magazine 32 (September 1987): 16-18.

Rocher, E., "Information Outlet: ULAN Versus ISDN," IEEE Communications Magazine 25 (April 1987): 18-32.

Rudd, S.E., "Interface Equipment and Systems in the Next Decade," Telecommunications, August 1987, pp. $55+$.

Scanlon, R.G., and J.K. Patterson, "Temple University and a Telecommunications Procurement Program," Technological Horizons in Education 11 (April 1984): 79-81.

Stephens, G.M., "Integrate? or Separate?" Satellite Communications 10 (June 1986): 20-22.

“Teleconferencing," ITC News 1 (December/January 1987/88): 7-8.

Trafton, D.R., "Gain That Competitive Edge Strategically-Through Planning," CommunicationAGE, January 1987, pp. 38-41.

Underwood, S., “ISDN on Trial," Datamation 33 (February 1, 1987): 52-56.

"University of Michigan Computing Organization," CauseEffect 8 (July 1985): 18-20.

Vennison A., "Trends: Oregon Public Access Catalog," Government Technology, April/May 1988, pp. 16-17.

"Vermont Creates Statewide Information System," Wilson Library Bulletin 59 (March 1985): 441 .

Welter, T.R., "Fiber Optics vs Satellites: Are They Competing or Complementary Technologies?" Industry Week 232 (February 23, 1987): $50+$.

West, T.W., "'The Development of a Network of Telecommunications Networks: A Contagion Period," CauseEffect 7 (September 1984): 2-3.

Wolf, M., "Long Distance Learning," State Legislatures, September 1987, pp. 22-23.

\section{Letters}

\section{The Information Fairy}

To the Editor:

It is a bit disconcerting to read "BI as Theatre" (C\&RL News, January 1989) and see the accompanying photograph of the Xavier University (Cincinnati) library's head of reader services, Vicki Young, dressed as "Ify, the Information Fairy" prepared to conduct a college freshman orientation program and, in the same month, read Linda Wallace's article in American Libraries, "The Image- and What You Can Do About It in the Year of the Librarian."

We have little quarrel with Young's attempt to refute "six major misconceptions about librarians and libraries," and we are glad that her presentation was "a big hit," but we really question whether it is necessary for any professional academic librarian to dress as an "Information Fairy" to "reduce students' anxiety" and to "present the library in a positive light."

It has been our experience, after over fourteen 